c/o The Zoological Society of London, Regent's Park, N.W. 1.

\title{
APPLICATION FOR MEMBERSHIP
}

I am interested in the work of the Society and should like to become a Member.

Name and Address (BLOCK LETTERS).

(Please state Mr., Mrs., Miss, or Title)

I enclose $£ \quad: \quad: \quad$ being my subscription as a Life/Ordinary Member.*

Please send me the following forms :-

Banker's Order. Deed of Covenant.

(Delete any of the above not applicable.)

* The annual subscription is $£ 2$, payable on 1st January. The value of a subscription is almost doubled if it is paid under a 7-year Deed of Covenant. The cost to the member of doing this is nothing at all.

The use of a Banker's Order is suggested as it saves time and expense.

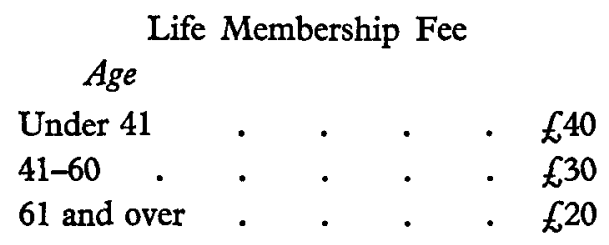






\section{Sunshine and smooth seas}

Every Thursday at 4 p.m. a Union-Castle liner leaves Southampton for

\section{SOUTH AFRICA}

serving the Cape Ports and Rhodesia.

Also sailings from London to Durtan via Mediterranean and East African Ports.

the going's good by

\section{UNION-CASTLE}

THE BIG SHIP WAYTO AFPICA

Chief Passenger Office, Rotherwick House, 19-21 Old Bond St. London W.1. Telephone: Hyde Park 8400 or Travel Agents. 


\section{Y Z CLUB - London Zoo and Whipsnade Park}

The Zoological Society of London invites children between the ages of 9 and 18 to join the Young Zoologists' Club.

\section{CLUB MEMBERSHIP}

The XYZ (Exceptional Young Zoologists) Club has been started for all young people who are interested in the Zoo, in natural history, and in animals generally.

\section{A WIDE RANGE OF ZOOLOGICAL TOPICS}

The Club, based on the London Zoo and Whipsnade, is designed to provide young zoologists with up-to-date information on the Zoos and, by means of free admission tickets, to help them to get to know our Zoos and the animals that live there really well.

But equally important, by means of lectures, films, and articles in the Club Magazine, they will be provided with information about a very wide range of zoological topics - wild life observation, general natural history and reviews of books and films that have a zoological interest.

\section{FREE ADMISSION TICKETS}

Entrance to the Club entitles all members to three free admission tickets each year to the London Zoo or Whipsnade Park, a Club Magazine published three times a year and a handsome Club badge.

There are regular competitions based on animal observation, field study competitions, painting and photography competitions, and film shows.

The Annual Subscription is I0s. and there are reduced rates for group membership which can be obtained on application to the Secretary of the Club, at the London Zoo, Regent's Park, N.W. I. 


\section{Screteen Austin a aos aro}

